\title{
Challenges and obstacles to access to justice in health care
}

\author{
Aart Hendriks
}

\section{Introduction}

Health is often a determining factor for a person's well-being and a parameter for his or her ability to function independently and participate autonomously in society. The latter also explains the importance we attach to health. Human health, however, defined, is therefore a very precious good. This is reflected by the fact that health has also been coined as a human right under international human rights law. The importance of health is acknowledged by EU law and other international and regional organizations, while the Dutch Constitution rather modestly stipulates that the State is required to take measures to promote public health. ${ }^{1}$

Despite all the advances in health research and the exponentially growing number of improved treatment options, human health is not a commodity. This also impacts on access to justice for both patients and health care providers, as will be argued in this contribution. The same holds true with respect to our body and its constituent parts, such as blood, organs and human tissue. We as human beings are not, legally speaking, the owners of our bodies, but we have say over it - often referred to as 'authority' or 'self-determination'. Human health and the human body must, according to Kantian theory of morality, never be treated as a means to an end. This explains, in a nutshell, why people cannot freely possess of their body as if it were their property and why medical liability cases are contested, given the (moral) difficulty to measure harm. Around the world, people are forbidden to treat their bodies and to expose themselves to forms of risks when considered contrary to the principles of humanity and human dignity. An example of such forms of commodification of human health and the human body is the selling of one's kidneys. For similar reasons, individual health care providers are professionals that should abide by the highest professional standards. Health care providers, like physicians and nurses, are therefore not merely 'repairers' of human health obliged to follow the instructions of their clients ('patients'). To the contrary, the professional autonomy of individual health care providers may collide with and generally overrules the autonomy of patients (individual self-determination) to choose for certain forms of treatment.

The special, almost sacral, status of human health and the human body as well as the professional responsibilities and duties of health care providers towards their patients have had a severe impact on access to justice for patients dissatisfied with the health care services provided to them, and the compensation they may wish to obtain for alleged medical faults. Challenging the quality and safety of the 
services of health care providers is even more difficult for patients now that health care providers generally possess more knowledge about health and treatment options than the average patient. This makes the patient vulnerable and dependent. All these factors add to the - real or perceived - inequality of powers between health care providers and patients, also negatively impacting on access to justice for the latter. But there are more reasons why access to justice for patients is not self-evident and why this issue merits further analysis.

For a long time, the provision of health care was surrounded by a myth of charity. This imposed an additional hurdle for patients to contest a form of treatment or the behaviour of a health care provider, let alone to do this before a tribunal, to claim compensation for damage they allegedly incurred. The charitable character of health care can be illustrated by pointing at the fact that health care providers often would not charge a fee, but an honorarium payment for their work by which way a patient could express his or her gratitude for the services received. Health care providers can also invoke the 'medical exception', to justify forms of treatment grossly violating the bodily integrity of a person, such as the amputation of a limb, the performance of a caesarean section or carrying out an operation. These interventions with the bodily integrity of a person normally constitute a criminal offence. When performed by a health care professional, however, the health care provider will be excluded from criminal liability - thus the term 'medical exception' - when he or she acted with the informed consent of the patient concerned and performed the act professionally. The 'medical exception' may otherwise pose a barrier for patients towards access to justice. To sum up, access to justice for patients is everything but self-evident.

In this contribution I will describe and analyze the extent to which access to justice is guaranteed in the health care sector in the Netherlands. In doing so I will start by examining the evolution of patients' rights in the Netherlands, with a focus on the right of a patient to litigate or otherwise file a complaint against a health care provider, as a corollary of access to justice for patients. Subsequently I will discuss how the strengthening of access to justice for patients and the need to safeguard the quality and safety of health care may threaten the fundamental rights of health care providers. At the end of this contribution, I will summarize the main conclusions.

\section{Access to justice for patients. Historical developments}

\subsection{From objects of care to persons with rights}

For a long time, patients were merely seen as objects of care rather than legal subjects with rights. It was only after the Second World War that patients' rights started to emerge in response to the atrocities committed during these dark years towards such groups as psychiatric patients and research subjects. Psychiatric patients were (and are) often deprived by their liberty, subjected to forced treatment and not in a position to enforce the enjoyment of other fundamental rights, whereas the latter were exposed to medical experiments, often without their prior knowledge, let alone permission. This background explains why the first 
generation of patients' rights notably aimed to protect the negative autonomy of the patient, emphasizing the right of patients to refuse forms of treatment and by allowing them to make their own choices with respect to health and health care. This was done by underlining the right to physical and mental integrity and by emphasizing respect for informed consent as a precondition for a medical intervention. In addition, all kind of substantive and procedural guarantees were introduced to protect the liberty of patients with mental health problems, contagious diseases or other conditions potentially dangerous for the persons themselves or others against the arbitrary deprivation of freedom and interferences with their integrity.

In a later stage, as of the late 1970s, the entitlements corresponding with positive autonomy, such as the right to health care and to health insurance, gradually and often reluctantly found legal recognition in the Netherlands and many other countries around the world. It became acknowledged that States should ensure equal access to health care and protect patients against all kind of health hazards, disseminate health information and prevent patients from being subjected to all kinds of treatment without their informed consent. Equally, States became obliged to respect choices patients made, including choices that could be detrimental to their health and life. Also, States became obliged to fulfil certain human rights obligations, such as with respect to access to essential health care and environmental protection. Thus the typology of human rights obligations - respect, protect, and fulfil - became fully applicable to health, turning health into a full human right.

Access to justice for patients emerged in a similar, seemingly haphazard way. But before turning to the right of a patient to complain, to sue or to otherwise institute a (quasi) legal procedure against a health care provider, allow me to refer briefly to probably the oldest way to hold health care providers responsible for professional misconduct and to guarantee the quality and safety of health care: medical disciplinary law.

\subsection{Medical disciplinary law}

Disciplinary law is, traditionally, a system of law to guarantee the proper functioning of the liberal professions, such as solicitors, notaries, members of the clergy and medical doctors. According to the Dutch Constitution, the State can introduce a system of disciplinary law. When doing so, this should be done by law. ${ }^{2}$ In the Netherlands, a system of disciplinary law for physicians was introduced in 1903. This was done by the Dutch Medical Association (Nederlandsche Maatschappij tot bevordering der Geneeskunst or NMG), a non-governmental organization representing physicians. This system of disciplinary law only applied to the members of this association. Since physicians were not required to become a member of the NMG, government felt that a private (association) law based system of disciplinary law fell short in upholding compliance with professional standards and in protecting the public at large. This resulted, in 1928, in the adoption of the Medical Disciplinary Act (Medische Tuchtwet or MTW), an administrative act 
applying to all physicians and a limited number of other care providers, independent on whether they were a member of the NMG or a similar association or not. Under the Medical Disciplinary Act, patients - besides others - were bestowed with the right to file a complaint against physicians, dentists, pharmacists, and midwifes. Up until today, plaintiffs are not required to pay a court fee when starting a disciplinary procedure. The aim of the 1928 act was, however, not to satisfy or otherwise compensate a patient but to promote and guarantee good standards of health care. The nature of disciplinary procedures were - and are - therefore not compensatory in nature and the measures imposed are not considered to be 'punitive' in terms of Article 6 of the ECHR. Thus, health care providers lack such legal guarantees as ne bis in idem and the right not to incriminate oneself. For patients who started a disciplinary procedure under this act, a disciplinary procedure is, however, often highly disappointing. In fact, their sole involvement was in the filing of a complaint. Otherwise, the patient had no say and the procedure was never meant to otherwise serve his or her individual rights or interests. In fact, the court procedures most often took place behind closed doors, and the disciplinary tribunals were dominated by medical professionals, fuelling the suspicion of a conspiracy of silence. Also other basic rights with respect to fair trial and due process, guaranteed by the - later adopted - European Convention on Human Rights (ECHR), were not guaranteed under the 1928 Medical Disciplinary Act, such as a public hearing and the presumption of innocence.

In 1997 the MTW became replaced by Chapter VII of the Individual Health Care Professions Act (Wet op de beroepen in de individuele gezondheidszorg 1993 or BIG). Even though the BIG introduced a number of changes with respect to disciplinary law - such as the number of professions subject to disciplinary law, the composition of the disciplinary courts, a public hearing, and the kind of measures that can be imposed in case of a well-founded complaint - these changes have not substantially altered the rights and interests of plaintiffs. The emphasis of disciplinary law remained on guaranteeing the proper functioning of the provision of health care and of individual health care providers, and not on doing justice to individual patients or otherwise offer compensation to patients that were exposed to unprofessional performance by a health care provider. In other words, medical disciplinary law cannot be considered as a means to promote access to justice for patients.

In this respect, it merits attention that patients, since 1958, can no longer make use of the internal disciplinary law system of the Dutch Medical Association (since 1949 royal, thus $K N M G$ ) to file complaints. After a long discussion within the medical association about the overlap between the public and private law based disciplinary law systems, the KNMG decided that only members of the association became entitled to file disciplinary complaints against each other under the KNMG system. 


\section{Patients' right to access to justice}

\subsection{Introduction}

As mentioned before, patients' rights emerged in the aftermath of the Second World War. This also holds true with respect to the Netherlands where patients' rights started to materialize as from the 1960 s and 1970s, more or less in tandem with the development of health law.

Access to justice, in terms of creating the necessary preconditions to litigate or otherwise start a (quasi) legal procedure against an individual or institutional health care provider, was not always the highest priority in the initial stages, as I will argue below. This may reflect a typical Dutch approach towards solving problems between patients and health care providers. Making use of a (quasi) legal procedure is generally perceived as a second best option to deal with such difficulties. It is commonly thought that the best way to solve problems, including questions with respect to financial liability, is by seeking an out-of-court bilateral settlement on the basis of the outcomes of a discussion between the parties involved, if necessary a dialogue facilitated by a complaints' officer, mediator, or other independent person. Having such a discussion depends, however, on the willingness of the parties involved to meet and speak and, if necessary, to apologize for what might have gone wrong. In my view, patients are and should not be required to (first) make use of an out-of-court option. An out-of-court procedure may not only be very burdensome but also may challenge access to justice. Access to a tribunal should therefore be guaranteed for those patients with complaints that meet a number of requirements. Let us therefore have a look of the legal procedures open to patients, besides the above-mentioned disciplinary law options.

\subsection{Medical liability law under civil law}

In the Netherlands, the main patients' rights act, the Medical Contract Law Act (Wet inzake de geneeskundige behandelingsovereenkomst, 1995, or Wgbo), has been integrated in the Civil Code (Burgerlijk Wetboek or BW). Under this law the relationship between a patient and a health care provider is defined as a contractual one, governed by the rules and principles of civil law with a number of inalienable rights for patients that cannot be derogated from, not even with the patient's consent.

This act contains just one reference to access to justice for the patient: a patient that has been treated in a health care institution can always hold the health care institution liable for medical negligence, even if the institution was not a party to the contractual relationship between one or more individual health care providers and the patient. ${ }^{3}$ Otherwise, the Wgbo and the Civil Code in general are silent on access to justice for patients.

What does this mean? A patient who holds the opinion that he or she is entitled to financial compensation for damage suffered as a result of a violation of his or her patients' rights or, more generally, of medical negligence or tort should start a civil law procedure. Depending on the height of the compensation claimed, the 
patient should then pay a court fee and bear the costs of legal aid. Although, the patient can ask for reimbursement of these costs after winning the case, he or she initially bears the risks of having to carry these costs. This may pose a substantial barrier for patients to start a civil law procedure against a health care provider. Moreover, under the Civil Code and thus under the Wgbo, the burden of proof lies with the party who lays charges ('claimant'). This means that he or she should produce all the necessary evidence to substantiate his or her claim when a case is presented in court. In medical liability cases, this is often a very difficult assignment for a patient who feels that he or she has been wronged by a health care provider. The patient generally lacks the knowledge and information to adequately substantiate his or her claim. This division of the onus of proof has therefore been criticized in the legal literature, but so far to no avail. Courts have modified the rules regarding the burden of proof in medical liability cases just in one respect, recognizing that patients otherwise would often encounter insurmountable barriers in acquiring necessary evidence. According to this modification, the defendant is bound to a heightened duty to plead (verzwaarde stelplicht), meaning that the defendant should, when pleading, provide all the evidence that the claimant might need to support his or her claim against the health care provider. Otherwise, the Dutch Highest Court with respect to civil law cases (Hoge Raad) has rejected to change the rules with respect to the burden of proof or otherwise to strengthen the position of the patient in medical liability cases. It should be emphasized here that courts in the Netherlands can change the rules with respect to the onus of proof if deemed in accordance with the principles of equity and natural justice. And neither the legislature has considered it necessary to foresee in different rules with respect to the burden of proof in health law.

Thus, it is not impossible for patients to obtain financial compensation, but providing facts from which it can be deducted that damage occurred due to an attributable medical mistake by a health care provider is not rarely a high barrier.

\subsection{Psychiatric patients}

In 1994, the Insanity Act of 1884 (Krankzinnigenwet) was replaced by the Psychiatric Hospitals Compulsory Admissions Act (Wet Bijzondere Opnemingen in Psychiatrische Ziekenhuizen or Bopz). One of the reasons to introduce a new act for psychiatric patients was to ensure that this body of law was in conformity with the ECHR. This has not only resulted in the codification of the rights of patients who due to a mental illness are being deprived of their liberty (Chapter III of Bopz, see also Article 5 of the ECHR and relevant case law), but also in the introduction of a right to complain for psychiatric patients with respect to a number of constraint measures that can be imposed on the basis of the Bopz. Such a complaint, that does not entail costs for the patient, should be sent to the board of the psychiatric hospital where the patient resides. The board should subsequently forward the complaint to a specially established complaints' committee that is bound to take a binding decision within 2 weeks after receipt of the complaint. The patient consequently has a possibility to challenge this decision in court.

The filing of a Bopz complaint, that - as said - merely concerns constraint measures such as isolation, does not automatically lead to the suspension of the con- 
tested measure. The complaints' committee and, in appeal, a court can however decide that the measure should be lifted.

All patients who involuntarily reside in a psychiatric hospital are entitled to the assistance and advice of the so-called patient's clinical treatment representative (patiëntenvertrouwenspersoon or PVP). The PVP can provide assistance when the patient considers filing a complaint under the Bopz. Also a family representative, like a spouse or child, and a legal representative, like a curator, can file a complaint on behalf of the patient. This is particularly important now that a psychiatric patient's mental capacity to file such a complaint may be impaired.

\subsection{A general right to complain}

Following the coming into force of the Bopz a new act was introduced bestowing all users of the health care sector with a right to file a complaint about the way they were treated by a health care provider. The aim of this act, the Right to Complain Act Clients Health Care Sector of 1995 (Wet klachtrecht cliënten zorgsector or $W k c z$ ), was to do justice to dissatisfied patients. A secondary goal of this act was to contribute to the quality of health care, in addition to such aims as the restoration of the relation of trust between the patient and health care provider and the reduction of the power inequality between the patient and health care provider. The legislature wanted to achieve these goals by requiring care providers that receive public funding to create a low threshold for clients to file a complaint and to ensure the careful investigation of a complaint. This act was introduced after it became clear that patients experienced difficulties in accessing the existing legal remedies to file complaints, such as a civil law or a disciplinary law procedure. The act also sought to ensure that care providers would benefit from complaints, by using the outcome of a complaint procedure as impetus to improve the quality and safety of care to make it better match the needs of patients.

Since the introduction of the Wkcz, all care providers receiving public funding are required to have a regulation for complaints and a complaints' committee that both meet a number of criteria set out in the Wkcz. Although not forbidden by law, complaints' committees do not levy a fee for a procedure; all costs are carried by the health care provider - and thus not by the State or another third party with the exception of legal aid should a party wish to receive the assistance of a legal expert. The complaints' committee is obliged to give its opinion within the period mentioned in the regulation for complaints. The committee can also make recommendations for the health care provider. Such an opinion as well as the recommendations are, however, non-binding for the health care provider. This is not to suggest that these opinions are void or otherwise of no importance. Within a month after receipt of the committee's opinion the health care provider is obliged by law to let the committee and the plaintiff know what the health care provider is going to do with the opinion and the possible recommendations.

Under the Wkcz there is no right to appeal for the complaining patient (or the defendant). The patient can neither otherwise ask for a revision of the opinion of the complaints' committee or its recommendations. On the other hand, complaints' committees are required, due to a new provision in the Wkcz in 2005, to bring to the attention of the health care provider complaints concerning a serious 
situation with a structural character. If the health care provider fails to take appropriate steps to improve the situation, then the complaints' committee is required to report its concern to the Health Care Inspectorate.

\subsection{Other options for patients}

Besides the above (quasi) legal options and the possibility to start disciplinary procedures against an individual health care provider $(\$ 2.2)$, patients have a few more options to express their dissatisfaction about the care they receive(d) and to try to get material or immaterial compensation for alleged substandard care. These opportunities can be seen as elaborations of the right to have access to justice for patients dissatisfied with the services provided to them by individual or institutional health care providers. In addition, reference should be made to two more options open to patients and a Bill currently pending in Parliament.

Firstly, since 1999 consumers and entrepreneurs' organizations created the Disputes' Committee (Geschillencommissie), a private initiative to facilitate out-ofcourt conflict resolution. Patients can file a complaint against entrepreneurs, including hospitals, who joined this committee. Many health care providers have joined the committee since 1999. The decisions of the committee are binding. In addition, the committee can award financial compensation up until $€ 5000$, per complaint to be paid by the entrepreneur to the plaintiff. Since the fee to be paid by the plaintiff, $€ 2750$, is relatively low (and will be returned in case the complaint is found grounded) and no legal representation is required, for many patients this is an attractive alternative for a civil law procedure.

Secondly, patients can file complaints with the National Ombudsman. The National Ombudsman examines whether a State organ has acted duly (behoorlijk), that is to say with sufficient care. A complaint procedure by the National Ombudsman does not entail costs for a plaintiff, since these are covered by a budget allotted to the National Ombudsman by Parliament. Despite this and the substantial powers the National Ombudsman has, the assistance of the National Ombudsman is hardly ever asked for by patients who are dissatisfied about the services of health care providers. This has everything to do with the scope of competence of the National Ombudsman. The law stipulates that the National Ombudsman is only authorized to investigate complaints against State organs, with some public law bodies even excluded. Health care providers, with the exception of (most) university hospitals, are all non-state organs. As a result, patients can only file complaints against State university hospitals acting as health care providers.

Thirdly, in July 2014 the Minister for Health, Welfare and Sports established a national clearinghouse for health complaints (Landelijk Meldpunt Zorg). This institution, falling under the responsibility of the Minister for Health and closely collaborating with the Health Care Inspectorate, gives advice and information on the resolution of complaints with respect to health care. In doing so, the clearinghouse can refer a dissatisfied patient to the most appropriate person or institution to express his or her complaint and, in case the defendant fails to respond in due course, can contact the health care provider on behalf of the patient. In addition - and from a legal viewpoint highly debatable - the clearinghouse passes on 
information, including the names of all health care providers patients have expressed concern about, to the Health Care Inspectorate who can undertake action. The clearinghouse itself does not have a task and neither the competence with respect to conflict resolution, also due to lack of a legal basis.

Fourthly and still optionally, a bill is pending in the Senate seeking to - as it is called - strengthen patients' rights with respect to complaints and disputes. This bill, the Act on Quality, Complaints and Disputes in Care (Wet kwaliteit, klachten en geschillen zorg, or $W \mathrm{kkgz}$ ), seeks to replace the Wkcz and some other pieces of legislation. Instead of an obligation for health care providers to have a complaints' committee, health care providers should under the Wkkgz have a complaints' officer with a task to find a peaceful resolution for a complaint. Different from the patient's clinical treatment representative (PVP) under the Bopz, who solely acts as patient's advocate, the complaints' officer is a more neutral and impartial intermediary between a patient and a health care provider. A complaints' committee becomes optional under the Wkkgz. Instead, health care providers become required to join a national or regional disputes committee with the authority to do binding decision, both with respect to immaterial complaints and financial disputes up until the sum of $€ 25,000$.

\section{Access to justice for health care providers}

\subsection{Introduction}

From the above, it can be learned that Dutch law foresees in various - and an increasing number of - avenues for patients to file complaints or to otherwise express their dissatisfaction about the way they have been treated by an individual or institutional health care provider, also by way of (quasi) legal procedures. But to what extent does Dutch law protect the rights of health care providers who allegedly did not treat a patient adequately? And does Dutch health law have possibilities for health care providers to institute a procedure against a patient? The answer to the latter question in: 'no'. Apart from the common legal instruments, notably starting a civil law procedure, there are no procedures health care providers can rely on when they feel that a patient has abused his or her rights. It is increasingly felt, at least by health care providers, that Dutch law falls short in adequately protecting the rights of health care providers. This can be illustrated by examining two topical issues.

\subsection{Right to reputation of health care providers}

Dutch law fiercely protects the freedom of expression. In line with the jurisprudence of the European Court of Human Rights (ECtHR) it is standing case law in the Netherlands that the right to freedom of expression not only protects the dissemination of information and ideas that are favourably received, but also - in the words of the ECtHR - 'those that offend, shock, or disturb'. Dutch courts acknowledge that the freedom of expression may collide with the right to private life, including the right to reputation, of others. When it comes to expressing views on health care providers that allegedly have provided bad services, the right 
to freedom of expression is given ample protection - often at the expense of the right to reputation of whom it concerns. It is only in rare instances that health care providers win legal procedures against patients who allegedly have committed libel or otherwise violated the right to reputation of a health care provider by spreading infamous information. Health care providers often consider this unfair, not in the last place because they can hardly defend themselves without breaching their duty to confidentiality. A health care provider who wants to challenge the accusations made by a patient concerning the services given can hardly do so without revealing information that falls within the realm of the duty of confidentiality. Almost the only legal remedy open to health care providers who are, in their view, falsely accused of negligence or other forms of misconduct is to demonstrate that the accusations are slanderous, disproportionately harmful to the reputation of a health care provider, completely unfounded and not serving a public aim. This makes is rather difficult for health care providers to stop, let alone prevent, expressions harmful to their reputation, even though there are cases where they successfully ordered the removal of such expressions from the social media.

\subsection{Punitive disciplinary law}

As was mentioned above, public disciplinary law is traditionally seen as a system of law to enhance the quality of the services of the members of certain liberal professions, with the possibility to take measures towards individual professionals who do not adhere to professional standards.

In line with the case law of the European Court of Human Rights, Dutch courts have held that the right to exercise a medical profession is a 'civil right' under Article 6 para 1 of the ECHR. This implies that medical professionals against whom disciplinary proceedings have been instituted are entitled to a fair trial, as guaranteed by Article 6 of the ECHR. But can disciplinary measures also be characterized as 'criminal charges', meaning that the enhanced guarantees of Article 6 paras 2-4 of the ECHR apply, including the presumption of innocence, the ne bis in idem principle, the right to legal assistance (Salduz), the principle of legality et cetera? So far, the ECtHR has not given a clear answer to this question. In the case Gautrin et al. v. France, the ECtHR referred to 'penalties' but did not distinguish between 'civil rights' and a 'criminal charge'. This seems to mean that the question to the answer whether a disciplinary measure equals a criminal charge depends on the domestic classification of the offences, the nature of the charge and the nature and severity of the penalty (cf. Engel). Despite of that, Dutch medical disciplinary courts have repeatedly held that disciplinary procedures cannot be qualified as a criminal charge. As a result, medical professionals are, for example, required to collaborate in a disciplinary procedure and provide material, including burdening documents, instead of being entitled to invoke the right to remain silent, are not provided with legal aid and also otherwise deprived of the rights a criminal suspect is entitled to. Moreover, criminal and disciplinary procedures are regularly instituted sequentially, with references made to the outcome in the 'other' procedure, not being marked as contrary to the principle of ne bis in idem. 
One can seriously doubt whether it is correct to classify disciplinary procedures in general as non-criminal. These doubts only increase taking into account a number of recent developments and announced measures emphasizing, at least in my view, the (also) punitive dimensions of disciplinary law. Let me illustrative this by giving a few examples.

Since July 2012 disciplinary reprimands must be published in the State Gazette and a regional newspaper, mentioning the full name of the health care professional as well as the nature of the offence. A reprimand, a disciplinary measure that does not affect the competence to exercise one's profession, can also be retrieved by consulting the files of the registration authority for a period of 5 years.

Since February 2015 the disciplinary courts hold that health care professionals can not only be disciplinary charged for what they have done in their capacity as a professional, but also for private conduct that may undermine the confidence of the public in the professional. In April 2015 the Central Disciplinary Court elaborated on this expansion of the scope of disciplinary accountability by ruling that also disrespectful behaviour towards colleagues and not telling the truth are subject to disciplinary review and can lead to disciplinary measures.

The Minister for Health has expressed the wish to further strengthen the punitive nature of disciplinary law. The Minister wants, amongst others, to introduce the possibility for disciplinary courts to impose a lifelong prohibition against pursuing one's profession, a proposal recently embraced by Parliament that wants the criminal court to impose such measures on health care providers. The latter is remarkable, since until now a prohibition against pursuing one's profession can only be imposed as a secondary measure by a criminal court in case of a very serious criminal offence and only for a period of maximally 5 years.

\section{Conclusions}

In this contribution, I have tried to describe and analyze the legal guarantees with respect to access to justice for the users and providers of health care in the Netherlands. It was noticed that over the course of the last few decades, patients' rights have gained importance. As a result of various laws, patients' rights towards health care providers were also strengthened.

Patients in the Netherlands have, nowadays, a large number of options to express their dissatisfaction about the services provided by an individual or institutional health care provider and can institute all kinds of (quasi) legal procedures, also in an effort to obtain financial compensation. It is, however, remarkable that these procedures were never introduced, let alone inspired, in an effort to ensure patients' right to access to justice. In fact, the concept of access to justice was always absent in the discussion surrounding the introduction of these procedures. That may also explain the haphazard way in which these procedures were introduced with a large diversity of preconditions for making use of them. In fact, without exaggeration one can easily assert that there is such an array of procedures patients can choose from when considering to institute proceedings against an institutional or individual health care provider that the patient easily gets lost 
in the legal jungle. This inspired the establishment of a national clearinghouse for health complaints (Landelijk Meldpunt Zorg) to assist and inform dissatisfied patients, although this above all reflects that the legislature has made things difficult for itself and for patients.

Access to justice for health care providers is even less guaranteed, now that their role is almost exclusively reduced to that of defendants. While patients can, simultaneously or sequentially, start a large number of procedures against a health care provider, a health care provider can merely start a civil law procedure against a patient - or report a crime in such cases as violence. Due to their duty of confidentiality it is, however, rather difficult for health care providers to start such a procedure or to defend themselves in case they are being accused by patients of misbehaviour or medical negligence, for example, on social media. Health care providers increasingly face that basic rights related to the concept of fair trial are encroached upon in parallel with the enhancement of disciplinary law. This branch of law is ever more used as an instrument to punish medical professional, however, without bestowing these professionals with the rights that should be respected in case of a criminal charge.

If laws and procedures were designed taking access to justice as a starting point, then they would have looked differently. Even though, both patients and health care providers are everything but satisfied with the existing body of procedures that can be invoked in case of complaints, there has - to the best of my knowledge - never been a discussion on reforming these procedures taking access to justice as a starting point. This is remarkable, as if access to justice is not considered to be a problem. As yet, it is difficult to say what should be done to change this perception, particularly if neither patients nor health care providers as well as their organizations advocate changes to this extent.

The overall conclusion of this contribution therefore is that the access to justice has not found an inroad in the health care sector yet. This is not to suggest that patients and health care providers are deprived of procedures and procedural guarantees, but these are not always in line with the warrants typical to access to justice. It would be interesting to systematically asses all the complaint procedures in the health care sector using access to justice as a yardstick to measure against. This will definitely lead to a more than gradual change is the legal landscape. 